\title{
Endocrinological and ophthalmological consequences of an initial endonasal endoscopic approach for resection of craniopharyngiomas
}

\author{
Peter G. Campbell, M.D., ${ }^{1}$ Brian McGettigan, M.D., ${ }^{2}$ Adam Luginbuhl, M.D., ${ }^{2}$ \\ Sanjay Yadla, M.D., ${ }^{1}$ Marc Rosen, M.D., ${ }^{2}$ and James J. Evans, M.D. ${ }^{1}$ \\ Departments of ${ }^{I}$ Neurosurgery and ${ }^{2}$ Otolaryngology, Thomas Jefferson University, Philadelphia, \\ Pennsylvania
}

\begin{abstract}
Object. The expanded endoscopic approach to craniopharyngiomas has recently been described in several small case series. The authors present their experience with this technique and review the available literature.

Methods. Between September 2006 and September 2009, 14 patients underwent a purely endoscopic, endonasal approach for resection of newly diagnosed craniopharyngiomas. These procedures represent index surgeries; no patient had undergone previous tumor resection. A retrospective review of endocrinological and ophthalmological outcomes, extent of resection, and complication prevalence was completed. Additionally, a review of the English literature was performed to evaluate outcomes of similar endoscopic techniques for resection of craniopharyngiomas.

Results. Four patients (28.6\%) underwent gross-total resection; near total resection or better was achieved in 9 patients $(64.3 \%)$. All patients presented with some form of visual field or acuity deficit. Postoperatively, 12 patients (85.7\%) experienced visual improvement, with 6 patients $(42.9 \%)$ having complete visual recovery. One patient experienced worsening of her visual deficit. Visual acuity improved in 8 patients $((57.1 \%)$, while visual field defects improved in $11(78.6 \%)$. The pituitary stalk was preserved in all cases. Eight $(57.1 \%)$ of 14 patients experienced some form of anterior pituitary dysfunction postoperatively. Although 9 patients $(64.3 \%)$ were documented to have either transient or permanent new diabetes insipidus immediately after surgery, at 1-month follow-up only 1 patient met clinical criteria. Five patients $(35.7 \%)$ developed CSF leaks that were successfully treated by subsequent endoscopic revision. All CSF leaks occurred early in the series. Two patients (14.2\%) were treated for presumed meningitis postoperatively.

Conclusions. The endoscopic endonasal approach is a minimally invasive alternative to open transcranial approaches for select craniopharyngiomas. Similar to previous transcranial series, rates of endocrinopathy and grosstotal resection were dependent upon the adherence of the tumor capsule to the hypothalamus, pituitary stalk, and associated vasculature. A review of the literature suggests that the results of the current series are similar to other published series on this topic. (DOI: 10.3171/2010.1.FOCUSO9292)
\end{abstract}

\begin{tabular}{|c|c|}
\hline KEY WORDS • & craniopharyngioma \\
\hline endonasal resection & endoscopic resection \\
\hline endocrinology & ophthalmology ～• \\
\hline
\end{tabular}

$\mathrm{C}$ RANIOPHARYNGIOMAS are rare tumors that originate from squamous epithelial remnants of the Rathke pouch. Craniopharyngiomas are designated as a WHO Grade I tumor, comprising 2 to $5 \%$ of all CNS tumors. ${ }^{43,57}$ Adamantinomatous and papillary histological subtypes of craniopharyngiomas have been described. The adamantinomatous type may be encountered at any age, but predominantly in the first 2 decades of life ${ }^{54}$ The papillary variety has been primarily reported in adults. ${ }^{1,54}$ Some authors report a lower recurrence rate with the papillary variety, while others have found no difference in surgical outcome or recurrence between the 2 subtypes..$^{1,17,54}$

\footnotetext{
Abbreviations used in this paper: $\mathrm{DI}=$ diabetes insipidus; GTR = gross-total resection; NTR $=$ near total resection; STR $=$ subtotal resection; $\mathrm{VP}=$ ventriculoperitoneal.
}

Despite a benign histological classification, craniopharyngiomas are often associated with a poor prognosis and their optimal treatment remains controversial. ${ }^{31}$

Secondary to mass effect, these tumors commonly lead to neurological, endocrinological, or visual symptoms. Patients with these tumors often present with impaired pituitary function. ${ }^{33}$ Reported rates for anterior pituitary hormone deficits prior to any operative intervention vary from 35 to $95 \%$ for growth hormone, 38 to $82 \%$ for follicle-stimulating hormone/luteinizing hormone, 21 to $62 \%$ for corticotrophin, and 21 to $42 \%$ for thyroid-stimulating hormone. ${ }^{32}$ Authors of large patient series have reported that between 6 and $38 \%$ of patients present with insufficient secretion of antidiuretic hormone. ${ }^{32}$ Because of the proximity of these tumors to the optic chiasm, bitemporal hemianopia has been reported 
TABLE 1: Patient and tumor characteristics*

\begin{tabular}{|c|c|c|c|c|}
\hline $\begin{array}{l}\text { Case } \\
\text { No. }\end{array}$ & $\begin{array}{l}\text { Age (yrs), } \\
\text { Sex }\end{array}$ & Presenting Complaint/Hx (duration) & $\begin{array}{l}\text { Tumor Con- } \\
\text { sistency }\end{array}$ & Tumor Size $(\mathrm{cm}) /$ Extension \\
\hline 1 & $44, \mathrm{M}$ & blurry vision (1 mo) & cystic/solid & $5.7 \times 4.0 \times 5.1 /$ suprasellar extending to 3 rd ventricle, subfrontal area \\
\hline 2 & $29, \mathrm{~F}$ & bitemporal visual field loss, HA & solid & $1.5 \times 1.1 \times 1.5 /$ sellar-suprasellar \\
\hline 3 & $56, \mathrm{M}$ & OD blindness, OS field deficits (2 wks) & cystic/solid & $2.8 \times 2.9 \times 2.6 /$ suprasellar compressing 3 rd ventricle \\
\hline 4 & $58, \mathrm{~F}$ & $\begin{array}{l}\text { progressive visual loss, cognitive deficits, } \\
\text { It hemiparesis }\end{array}$ & solid & $\begin{array}{l}2.6 \times 4.1 \times 3.8 / \text { sellar-suprasellar compressing } 3 \text { rd ventricle, } \\
\text { hypothalamus }\end{array}$ \\
\hline 5 & $24, \mathrm{M}$ & $\begin{array}{l}\text { progressive visual loss OD > OS, HA } \\
(1 \mathrm{mo})\end{array}$ & cystic/solid & $3.6 \times 2.1 \times 2.9 /$ sellar-suprasellar compressing hypothalamus \\
\hline 6 & $18, \mathrm{M}$ & $\begin{array}{l}\text { hydrocephalus, progressive visual loss, } \\
\text { endocrinopathy ( } 3 \text { yrs) }\end{array}$ & cystic/solid & $\begin{array}{l}5.8 \times 6.4 \times 8.1 / \text { sellar-suprasellar extending to subfrontal area, corpus } \\
\text { callosum }\end{array}$ \\
\hline 7 & $34, \mathrm{M}$ & progressive visual loss, OS > OD (2 mos) & cystic/solid & $3.5 \times 2.7 \times 3.1 /$ sellar-suprasellar compressing 3rd ventricle \\
\hline 8 & $65, \mathrm{~F}$ & OD blindness, HA (3 mos) & cystic & $1.7 \times 2.6 \times 2.2 /$ sellar-suprasellar \\
\hline 9 & $38, \mathrm{M}$ & progressive visual loss, $\mathrm{HA}$ & cystic/solid & $1.5 \times 2.9 \times 2.2 /$ sellar-suprasellar compressing 3 rd ventricle/hypothalamus \\
\hline 10 & $56, \mathrm{M}$ & progressive visual loss & cystic/solid & $\begin{array}{l}2.0 \times 1.5 \times 1.9 / \text { suprasellar tumor w/ } 1.3 \times 2.5 \times 1.2 \text { cystic compression of } \\
\text { the } 3 \text { rd ventricle }\end{array}$ \\
\hline 11 & $64, \mathrm{~F}$ & bitemporal hemianopsia, HA & solid & $1.5 \times 1.9 \times 1.8 /$ suprasellar \\
\hline 12 & $49, \mathrm{M}$ & progressive visual loss, $\mathrm{HA}$ & cystic/solid & $2.0 \times 2.0 \times 1.7 /$ suprasellar compressing 3rd ventricle \\
\hline 13 & $51, \mathrm{M}$ & $\begin{array}{l}\text { hydrocephalus, progressive visual loss, } \\
\text { HA (2 mos) }\end{array}$ & solid & $3.9 \times 2.9 \times 3.8 /$ suprasellar involving 3rd ventricle \\
\hline 14 & $55, \mathrm{~F}$ & blurry vision, HA, It face/arm pain (1 yr) & cystic/solid & $\begin{array}{l}3.2 \times 4.3 \times 3.6 / \text { suprasellar compressing } 3 \text { rd ventricle, hypothalamus, } \\
\text { thalamus }\end{array}$ \\
\hline
\end{tabular}

* All measurements are given in superior/inferior $x$ anteroposterior $\times$ transverse dimensions. Abbreviations: $H A=$ headache; $O D=o c u l u s$ dexter (right eye); OS = oculus sinister (left eye).

in as many as $49 \%$ of cases. ${ }^{3,17}$ In children and adolescents, some authors have reported that presenting signs or symptoms are more typically related to increased intracranial pressure or sexual immaturity., ${ }^{2,50}$

Craniopharyngiomas remain one of the most difficult tumors to treat effectively. Adherence to the pituitary stalk, hypothalamus, and anterior cerebral vessels often makes complete resection unattainable..$^{49}$ Involvement of surrounding critical structures, diminutive intraoperative visualization, distorted anatomical relationships, and limited sharp dissection often hinders complete resection regardless of approach. ${ }^{49}$ These tumors have traditionally been surgically removed via a microscopic transcranial approach, whereas the transsphenoidal approach, either microsurgical or endoscopic, has been recently used to access intrasellar or subdiaphragmatic tumors. ${ }^{28,39}$ With the increasing use of endoscopic techniques and the improved illumination and expansive view they provide, endonasal approaches have shown efficacy and safety in treating certain midline lesions of the cranial base beyond the sellar region. ${ }^{15,19,29}$ These approaches provide direct access to pathology, reduce brain retraction and manipulation of the optic chiasm, and may decrease hospital stay and morbidity. 4,8

The endoscopic endonasal approach is emerging as a credible surgical alternative for removal of select suprasellar craniopharyngiomas. . $^{9,13,15,24} \mathrm{We}$ present a series of 14 cases in which a purely endoscopic, endonasal approach was chosen for the initial resection of craniopharyngiomas. This case series consisted of tumors that ad- vanced superiorly and laterally to the sella, posteriorly to the optic chiasm, and (in some) extended into the third ventricle. Short-term ophthalmological and endocrinological outcomes as well as the extent of resection are reported. A literature review of previously published case series and outcomes after endoscopic endonasal resection is presented.

\section{Methods}

\section{Study Population}

After obtaining the approval of the Thomas Jefferson University institutional review board to conduct the study, we retrospectively reviewed the medical records of 20 patients who presented to our institution with pathologically confirmed craniopharyngioma between September 2006 and September 2009. Only index surgeries were reviewed; patients with any previous operative interventions or radiotherapy were excluded. Fourteen adult patients ultimately comprised the study population. All patients underwent full preoperative endocrine laboratory evaluations, which were repeated 1 month postoperatively. All patients underwent formal visual field and visual acuity evaluation pre- and postoperatively. Neuroradiological evaluation included skull base protocol MR imaging, with and without intravenous contrast enhancement, as well as high-resolution CT scanning of the craniofacial bones and sella. Postoperative MR imaging was performed within 24 hours of surgery and repeated at 3 


\section{Outcomes in initial endoscopic resection of craniopharyngioma}

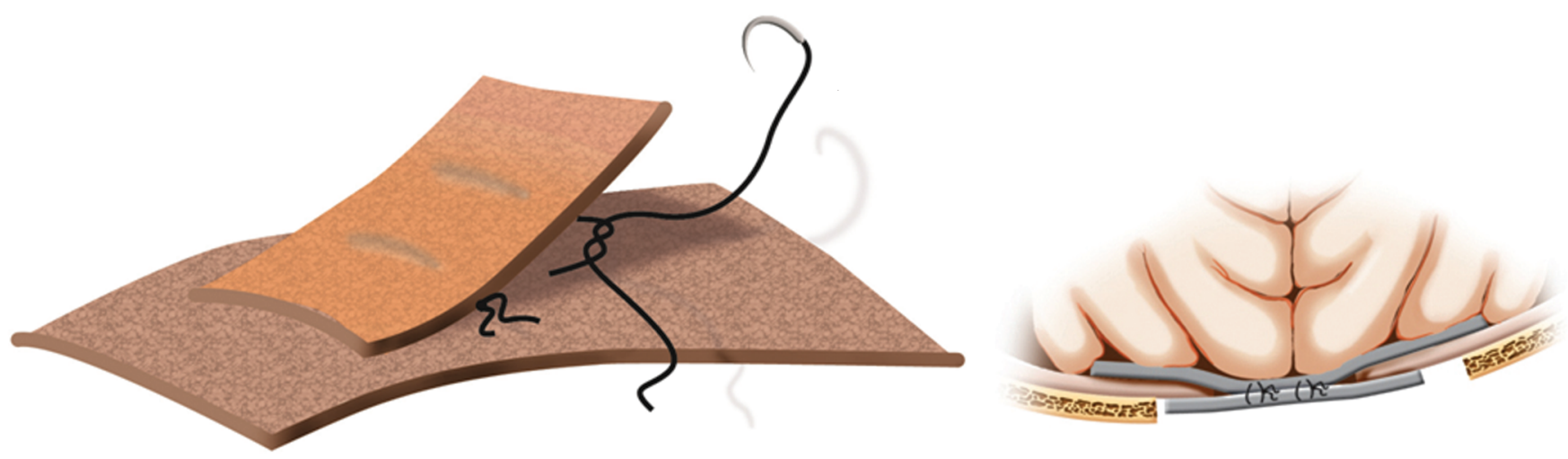

FIG. 1. Illustration of the creation of a "button" graft. Left: Two pieces of fascia lata are yoked together using a suture. Right: After placement in the skull base dural defect; note that the inlay graft is larger than the onlay portion.

months to confirm the extent of tumor removal. Interpretation of the 3-month MR imaging results was independently performed by a neuroradiologist.

Patients ranged in age from 18 to 65 years, with a mean age of 45 years. The series consisted of 9 men and 5 women (Table 1). Tumors ranged from 1.5 to $5.8 \mathrm{~cm}$ at their largest dimension. All tumors extended beyond the sella and 7 compressed the third ventricle. All patients demonstrated some objective visual abnormalities at presentation. One patient (7.1\%) presented to the emergency department with DI and the tumor was discovered as a causative factor during further investigation. Seven (50\%) of the 14 patients presented with some form of anterior pituitary dysfunction. Length of stay and perioperative complications were recorded and analyzed using logistic regression analysis.

\section{Operative Technique}

The initial operative technique for endonasal endoscopic resection of midline skull base lesions has been previously reported in detail in other case series; the approach used in the current series does not differ significantly from that described in the literature. . $^{0,13,34,49}$ However, reconstruction represents one of the most challenging steps of the expanded approach and the current authors have developed a multilayered closure using a 2-layer fascia lata "button" graft to seal the dural defect. The "button" is constructed of 2 pieces of fascia lata attached to one another by suture (Fig. 1). One layer of the button is inserted inside the defect as an inlay while the other layer lies over the dura as an onlay. The position of the inlay may be manipulated by moving the onlay, since the two are anchored. A nasoseptal flap is then placed against the skull base over the button graft. The graft is secured with synthetic glue (DuraSeal, Confluent Surgical). The middle turbinates are medialized, both to restore normal sinus function and to protect the exposed resection bed. Sheets of Gelfilm (Pfizer) are then placed between the septum and middle turbinate, and in the ostiomeatal complex. No catheters, stents, or balloons are used in this reconstruction.

\section{Literature Review}

A literature review of the MEDLINE bibliographic database was performed. Using the key words "craniopharyngioma," "endoscopic," "endonasal," "transsphenoidal," and "surgery," 7 case series devoted to endoscopic endonasal resections of craniopharyngiomas were identified. By searching the bibliographic contents of this series, 1 additional report was found. Case reports were not included in this analysis.

\section{Results}

\section{Evaluation of Tumor Resection}

The extent of tumor resection was recorded as a GTR when 3 criteria were met: the senior author (J.J.E.) believed no residual disease was present postoperatively, and the immediate postoperative and 3-month followup MR imaging findings documented no evidence of residual disease on either scan. In the current series, 4 (28.6\%) of 14 patients met these criteria (Table 2; Fig. 2). An NTR was achieved in $5(35.7 \%)$ of 14 patients, indicating removal of at least $95 \%$ of the tumor burden. In this group, total resection was limited by residual adherence to neurovascular structures in 2 patients, hypothalamic involvement in 2 patients, and the fifth patient expressed a strong preference for minimal resection favoring the preservation of pituitary function. A statistical ANOVA was performed on the extent of resection as it related to tumor volume. In this analysis, the extent of resection was significantly more likely to be greater in tumors of smaller volume $(\mathrm{p}=0.033)$. The pituitary stalk was preserved in all 14 patients.

\section{Ophthalmological Results}

All 14 patients underwent ophthalmological evaluation before and after surgical intervention (Table 3). Patients were referred to a neuroophthalmologist for visual acuity as well as formal perimetry and visual field testing. All patients showed evidence of visual defects preoperatively. Bitemporal hemianopsia was the most frequent ophthalmological finding, noted in $7(50 \%)$ of 14 patients. Postoperatively, $12(85.7 \%)$ of 14 patients experienced some visual improvement, with normal vision attained in $6(42.9 \%)$ of 14 patients after tumor resection. Postoperatively, 11 patients $(78.6 \%)$ showed an improvement in visual fields upon testing, while 8 (57.1\%) demonstrated 
TABLE 2: Summary of extent of resection, evaluation of residual disease, and pathological subtype of craniopharyngioma*

\begin{tabular}{|c|c|c|c|c|c|}
\hline $\begin{array}{l}\text { Case } \\
\text { No. }\end{array}$ & Initial Postop Evaluation of Tumor Resection & Radiographic FU at 3 mos & $\begin{array}{l}\text { Radiographic } \\
\text { Residual Dis- } \\
\text { ease at } 3 \text { mos }\end{array}$ & $\begin{array}{l}\text { Ulti- } \\
\text { mate } \\
\text { Result }\end{array}$ & $\begin{array}{c}\text { Final } \\
\text { Pathology (type) }\end{array}$ \\
\hline 1 & $\begin{array}{l}\text { STR, residual adherent to neurovascular } \\
\text { structures }\end{array}$ & $\begin{array}{l}\text { crescent-shaped residual tumor } \\
\text { enhancement }\end{array}$ & yes & STR & adamantinomatous \\
\hline 2 & NTR, residual where adherent to pituitary stalk & residual sellar tissue enhancement & yes & NTR & adamantinomatous \\
\hline 3 & $\begin{array}{l}\text { NTR, residual where adherent to medial } \\
\text { hypothalamus }\end{array}$ & partially enhancing suprasellar mass & yes & NTR & papillary \\
\hline 4 & STR, residual adherent to infundibulum & residual enhancement & yes & STR & papillary \\
\hline 5 & GTR & GTR & no & GTR & adamantinomatous \\
\hline 6 & $\begin{array}{l}\text { STR, residual adherent to neurovascular } \\
\text { structures }\end{array}$ & large residual sellar-suprasellar mass & yes & STR & adamantinomatous \\
\hline 7 & $\begin{array}{l}\text { STR, residual adherent to neurovascular } \\
\text { structures }\end{array}$ & peripheral rim/nodular enhancement & yes & STR & adamantinomatous \\
\hline 8 & GTR & enhancement of chiasm, likely residual tumor & yes & NTR & adamantinomatous \\
\hline 9 & GTR & GTR & no & GTR & adamantinomatous \\
\hline 10 & GTR & GTR & no & GTR & adamantinomatous \\
\hline 11 & NTR, residual adherent to hypothalamus & minimal residual tissue in suprasellar region & yes & NTR & papillary \\
\hline 12 & GTR & GTR & no & GTR & adamantinomatous \\
\hline 13 & STR, residual adherent to optic chiasm & large residual sellar-suprasellar mass & yes & STR & adamantinomatous \\
\hline 14 & NTR, residual adherent to hypothalamus & residual cystic suprasellar mass & yes & NTR & adamantinomatous \\
\hline
\end{tabular}

* GTR indicates no radiographic evidence of residual tumor; NTR indicates $\geq 95 \%$ removal; STR indicates < 95\% removal. Abbreviation: FU = follow-up.

an improvement in acuity. One patient was found to have worsened visual acuity postoperatively.

\section{Endocrinological Results}

All patients underwent endocrinological evaluation both preoperatively and 1-month postoperatively with complete serum endocrine panels (Table 4). One patient presented with panhypopituitarism. Seven patients showed no preoperative deficits in anterior pituitary function. Postoperatively, 1 patient experienced new adrenal
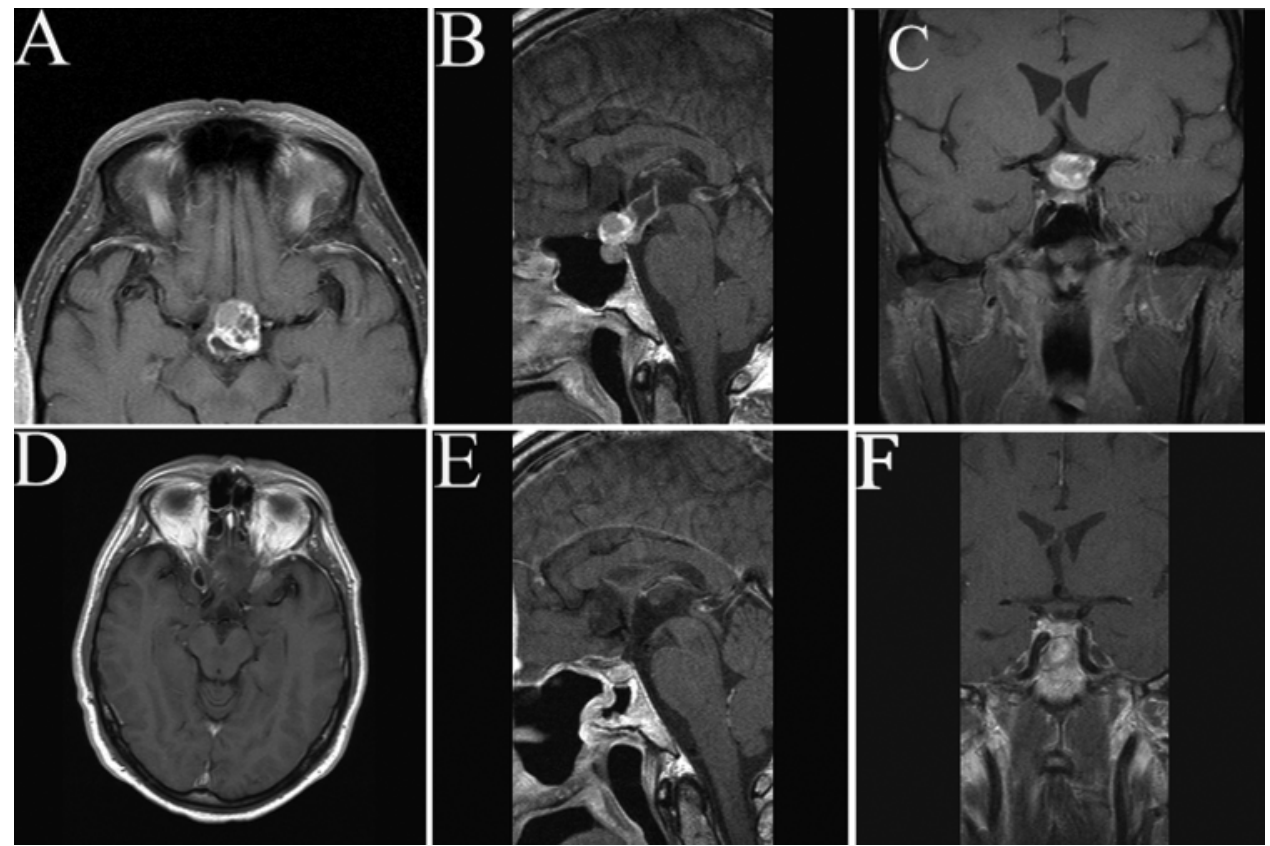

FIG. 2. Preoperative $(A-C)$ and postoperative $(D-F)$ contrast-enhanced $M R$ images of a patient with a craniopharyngioma. Axial (A), sagittal (B), and coronal (C) views of a $2.0-\mathrm{cm}$ (solid) and $2.5-\mathrm{cm}$ (cystic) tumor. Axial (D), sagittal (E), and coronal (F) views obtained at the 3-month follow-up showing a GTR of the lesion. 
Outcomes in initial endoscopic resection of craniopharyngioma

TABLE 3: Ophthalmological results*

\begin{tabular}{|c|c|c|c|c|}
\hline $\begin{array}{l}\text { Case } \\
\text { No. }\end{array}$ & $\begin{array}{l}\text { Presenting Ophthalmo- } \\
\text { logical Sx (duration) }\end{array}$ & Preop Evaluation & Postop Evaluation & Final Assessment \\
\hline 1 & blurry vision (1 mo) & $\begin{array}{l}\text { OD temporal hemianopsia 20/200, } \\
\text { OS NLP }\end{array}$ & $\begin{array}{l}\text { OD temporal hemionopsia 20/70, } \\
\text { OS NLP }\end{array}$ & improved \\
\hline 2 & bitemporal visual field loss & $\begin{array}{l}\text { OD temporal hemianopsia } 20 / 25 \\
\text { OS temporal hemianopsia } 20 / 15\end{array}$ & $\begin{array}{l}\text { OD full visual fields } 20 / 25 \\
\text { OS full visual fields } 20 / 15\end{array}$ & improved, normalized \\
\hline 3 & $\begin{array}{l}\text { OD blindness, OS field } \\
\text { deficits ( } 2 \text { wks) }\end{array}$ & $\begin{array}{l}\text { OD temporal hemianopsia 20/800, } \\
\text { OS temporal hemianopsia 20/200 }\end{array}$ & minimal bitemporal hemianopsia & improved \\
\hline 4 & progressive visual loss & $\begin{array}{l}\text { OD temporal hemianopsia 20/40, } \\
\text { OS temporal hemianopsia 20/70 }\end{array}$ & $\begin{array}{l}\text { OD temporal hemianopsia 20/200, } \\
\text { OS temporal hemianopsia 20/100 }\end{array}$ & declined \\
\hline 5 & $\begin{array}{l}\text { progressive visual loss OD } \\
\quad>\mathrm{OS}(1 \mathrm{mo})\end{array}$ & $\begin{array}{l}\text { OD 20/400, OS superior temporal } \\
\text { quadrantanopsia } 20 / 20\end{array}$ & $\begin{array}{l}\text { OD 20/25, OS improved superior } \\
\text { temporal quadrantanopsia } 20 / 20\end{array}$ & improved \\
\hline 6 & $\begin{array}{l}\text { progressive visual loss } \\
\text { (3 yrs) }\end{array}$ & $\begin{array}{l}\text { OD central vertical deficit, restricted up- } \\
\text { ward gaze, able to count fingers; OS NLP }\end{array}$ & $\begin{array}{l}\text { OD full visual fields, weak lateral gaze; } \\
\text { OS NLP }\end{array}$ & improved \\
\hline 7 & $\begin{array}{l}\text { progressive visual loss OS } \\
\quad>\mathrm{OD}(2 \mathrm{mos})\end{array}$ & $\begin{array}{l}\text { OD inferior temporal quadrantanopsia } \\
20 / 400, \text { OS 20/400 }\end{array}$ & $\begin{array}{l}\text { OD 20/50, full visual fields; } \\
\text { OS } 20 / 20 \text {, full visual fields }\end{array}$ & improved \\
\hline 8 & OD blindness (3 mos) & OD temporal hemianopsia, OS NLP & $\begin{array}{l}\text { OD inferior temporal quadrantanopsia } \\
20 / 100, \text { OS full visual fields 20/25 }\end{array}$ & improved \\
\hline 9 & progressive visual loss & $\begin{array}{l}\text { OD diminished peripherally all quadrants, } \\
\text { OS full visual fields }\end{array}$ & $\begin{array}{l}\text { OD full visual fields, } \\
\text { OS full visual fields }\end{array}$ & improved, normalized \\
\hline 10 & progressive visual loss & $\begin{array}{l}\text { OD superior/inferior temporal hemianopsia, } \\
\text { OS superior/inferior nasal hemianopsia }\end{array}$ & $\begin{array}{l}\text { OD full visual fields, } \\
\text { OS full visual fields }\end{array}$ & improved, normalized \\
\hline 11 & bitemporal hemianopsia & $\begin{array}{l}\text { OD temporal hemianopsia, } \\
\text { OS temporal hemianopsia }\end{array}$ & $\begin{array}{l}\text { OD full visual fields, } \\
\text { OS full visual fields }\end{array}$ & improved, normalized \\
\hline 12 & progressive visual loss & $\begin{array}{l}\text { OD temporal hemianopsia } 20 / 50, \text { OS } \\
\text { superior temporal quadtrantopia } 20 / 100\end{array}$ & $\begin{array}{l}\text { OD full visual fields, } \\
\text { OS full visual fields }\end{array}$ & improved, normalized \\
\hline 13 & progressive visual loss & $\begin{array}{l}\text { OD partial temporal field deficit, } \\
\text { OS partial temporal field deficit }\end{array}$ & $\begin{array}{l}\text { OD full visual fields, } \\
\text { OS full visual fields }\end{array}$ & improved, normalized \\
\hline 14 & blurry vision & $\begin{array}{l}\text { OD full visual fields } 20 / 200 \\
\text { OS full visual fields } 20 / 70\end{array}$ & $\begin{array}{l}\text { OD full visual fields, } \\
\text { OS full visual fields }\end{array}$ & no change \\
\hline
\end{tabular}

* NLP $=$ no light perception.

insufficiency requiring steroid replacement at 1-month follow-up and 1 patient experienced resolution of adrenal insufficiency. Seven patients demonstrated preoperative deficits in 1 or more hormones secreted by the anterior pituitary axis. Three of these 7 patients experienced a new, single-axis, low serum cortisol requiring hormone replacement. Overall, 9 patients $(64.3 \%)$ showed no change in their anterior pituitary function, 4 (28.6\%) experienced a worsening of preoperative anterior pituitary function in at least 1 axis, and 1 (7.1\%) showed an improvement.

Diabetes insipidus was present preoperatively in 1 (7.1\%) of 14 patients (Table 4). Postoperatively, 9 patients (64.3\%) experienced new DI, according to serum sodium, urine osmolality, and urinary output requiring desmopressin. In 4 patients the DI was transient, resolving after 1 to 5 doses of desmopressin (average of 2 doses). Five (35.7\%) of 14 patients had DI at the time of discharge requiring continued administration of desmopressin. However, at the 1-month follow-up evaluation, only 1 patient (7.1\%) met clinical criteria for DI requiring continued treatment with desmopressin (considered permanent DI).

\section{Postoperative Complications}

Complications related to surgical intervention are listed in Table 5. One patient experienced a decrease in visual acuity postoperatively (Table 3). Although there was a preoperative visual deficit with reported recent deterioration, postoperatively there was further worsening in the patient's acuity. No patient died during or as a direct result of endoscopic surgery or during the 30-day postoperative period. However, 1 patient who underwent a partial endoscopic resection followed by an open transcranial approach ultimately developed hydrocephalus followed by multiple shunt failures and revisions. This patient died after a withdrawal of support order was initiated 6 months after the initial procedure. No other patient experienced new permanent neurological deficits. Two $(14.3 \%)$ of 14 patients in this series were treated for meningitis; one for Haemophilus influenzae infection and another for presumed meningitis secondary to an elevated CSF white blood cell count at the recommendation of the infectious disease service, although no infectious organism was ever identified.

In the current case series, the most common complication was CSF leak, occurring in 5 patients (35.7\%). Lumbar drains were used preoperatively in 5 patients. All patients with CSF leaks underwent a successful primary endoscopic repair. Two patients (14.3\%) required long- 
TABLE 4: Endocrinology results*

\begin{tabular}{|c|c|c|c|c|c|c|}
\hline \multirow[b]{2}{*}{$\begin{array}{l}\text { Case } \\
\text { No. }\end{array}$} & \multicolumn{2}{|c|}{ Anterior Pituitary Function } & \multicolumn{4}{|c|}{ Posterior Pituitary Function } \\
\hline & Preop Deficit & Postop Deficit & $\begin{array}{l}\text { Preop } \\
\text { DI }\end{array}$ & $\begin{array}{l}\text { Post- } \\
\text { op DI }\end{array}$ & $\begin{array}{l}\text { Postop DI at } \\
\text { Discharge }\end{array}$ & $\begin{array}{l}\text { New Perma- } \\
\text { nent DI }\end{array}$ \\
\hline 1 & none & none & no & yes & yes & yes \\
\hline 2 & hypogonadism, hyperprolactinemia & hypogonadism, hyperprolactinemia & no & no & no & no \\
\hline 3 & hypothyroidism, hypogonadism, hyperprolactinemia & $\begin{array}{l}\text { Al, hypothyroidism, hypogonadism, } \\
\text { hyperprolactinemia }\end{array}$ & no & yes & no & no \\
\hline 4 & hypothyroidism, hypogonadism, hyperprolactinemia & $\begin{array}{l}\text { Al, hypothyroidism, hypogonadism, } \\
\text { hyperprolactinemia }\end{array}$ & no & yes & yes & no \\
\hline 5 & hypogonadism & Al, hypothyroidism, hypogonadism & no & yes & no & no \\
\hline 6 & panhypopituitarism & panhypopituitarism & no & yes & no & no \\
\hline 7 & none & none & no & yes & no & no \\
\hline 8 & none & none & no & no & no & no \\
\hline 9 & hyperprolactinemia & none & no & yes & yes & no \\
\hline 10 & none & none & no & yes & no & no \\
\hline 11 & Al, hypothyroidism & hypothyroidism & no & no & no & no \\
\hline 12 & none & $\mathrm{Al}$ & yes & yes & yes & no \\
\hline 13 & none & none & no & no & no & no \\
\hline 14 & Al, hypogonadism, hyperprolactinemia & Al, hypogonadism, hyperprolactinemia & no & yes & yes & no \\
\hline
\end{tabular}

* $\mathrm{Al}=$ adrenal insufficiency.

term CSF diversion for treatment of hydrocephalus. One patient experienced a leak 1-month postoperatively, which ultimately required long-term CSF diversion; a VP shunt was also required in another patient after lumbar puncture demonstrated elevation of intracranial pressure. Logistic regression analysis of the date of surgery and the time of the CSF leaks showed a statistically significant decrease in the CSF leak rate as the endoscopic experience progressed ( $\mathrm{p}=0.0481$; OR 0.97, 95\% CI 0.94-0.99).

\section{Length of Hospital Stay}

The duration of hospital stay varied from 3 to 14 days (median 9 days). No significant relationship between CSF leak and length of stay was found. However, 2 of the 5 patients with postoperative CSF leaks were discharged home and subsequently required readmission from the emergency department for treatment of CSF rhinorrhea.

\section{Discussion}

Complete resection for craniopharyngiomas has been shown to provide a survival benefit, but often at the expense of neurological, ophthalmological, and endocrinological function. ${ }^{42,53}$ Authors have reported GTR rates ranging from 5 to $90 \%$. 3,5,7,9,14,20,26,37,40,42,47,51-53,56 Yaşargil et al. ${ }^{56}$ was able to achieve a $90 \%$ GTR rate, but reported a $9.0 \%$ rate of intraoperative and early postoperative mortality and a $16.7 \%$ overall mortality rate. Given the morbidity and mortality associated with GTRs, some investigators have advocated STR combined with postoperative radiation as an alternative when the risk of a GTR would likely be associated with formidable morbidity. ${ }^{36}$ Several authors have reported similar disease control rates after partial resection and postoperative radiotherapy as compared with GTR, with decreased perioperative complication rates. ${ }^{14,22,36,41,45,55}$

When compared with the more traditional microscopic transsphenoidal approaches, the use of the endoscope provides the surgeon with a more expansive volumetric exposure of the skull base, theoretically enhancing the extent of resection, while providing a safety profile not available with microscopy alone. Accordingly, several authors have reported on the addition of an endoscope to augment visualization of remaining tumor during microscopic resections. ${ }^{12,18}$ In a series of 800 patients, Fatemi et al. ${ }^{21}$ examined the benefits and limitations of the microscopic endonasal approach to the sella and reported little difficulty with removal of standard microadenomas, but encountered formidable challenges when attempting to remove larger suprasellar nonadenomatous lesions. Studies report rates of GTR after microscopic transsphenoidal surgery that range from 6.9 to $90 \% .^{11,37,40}$ Chakrabarti et al. ${ }^{11}$ presented 5-year outcome data on 68 patients undergoing standard and expanded transnasal craniopharyngioma resection; in this study, 34 new cases of anterior pituitary dysfunction occurred postoperatively, along with 41 new cases of DI (67\%). Tumor size was not available for consideration, introducing a possible selection bias, because patients harboring larger tumors may have been assigned to an open craniotomy. Endoscopic endonasal series in the literature to date have reported greater preservation and recovery of endocrinological and ophthalmological outcomes, with possibly a lesser extent of resection (Table 6).

In the current series, although insufficiently powered to allow for a direct comparison with these larger series, the rates of resection are comparable to historical 
Outcomes in initial endoscopic resection of craniopharyngioma

TABLE 5: Postoperative complications*

\begin{tabular}{|c|c|c|c|c|}
\hline $\begin{array}{l}\text { Case } \\
\text { No. }\end{array}$ & $\begin{array}{l}\text { LOS } \\
\text { (days) }\end{array}$ & Complication & Treatment & Result \\
\hline 1 & 12 & fevers, culture negative lumbar puncture, high CSF white blood cell count & intravenous antibiotics & resolution \\
\hline 2 & 2 & none & NA & NA \\
\hline 3 & 8 & CSF leak, pneumocephalus, hydrocephalus & endoscopic repair, ventriculostomy & resolution \\
\hline 4 & 6 & CSF leak, pneumocephalus, hydrocephalus & endoscopic repair, VP shunt & resolution \\
\hline 5 & 11 & CSF leak, pneumocephalus & endoscopic repair, lumbar drain & resolution \\
\hline 6 & 10 & none & NA & NA \\
\hline 7 & 3 & none & NA & NA \\
\hline 8 & 14 & CSF leak, hematoma at abdominal donor site & $\begin{array}{l}\text { endoscopic repair, lumbar drain, } \\
\text { hematoma evacuation }\end{array}$ & resolution \\
\hline 9 & 10 & meningitis & antibiotics & resolution \\
\hline 10 & 6 & none & NA & NA \\
\hline 11 & 11 & none & NA & NA \\
\hline 12 & 10 & none & NA & NA \\
\hline 13 & 5 & CSF leak and hydrocephalus 1-mo postop, multiple cystic recurrences & $\begin{array}{l}\text { endoscopic repair, lumbar drain, } \\
\text { VP shunt }\end{array}$ & $\begin{array}{l}\text { death from shunt } \\
\text { failure }\end{array}$ \\
\hline 14 & 6 & none & NA & NA \\
\hline
\end{tabular}

* LOS = length of stay; NA = not applicable.

case series. Within endonasal endoscopic series for craniopharyngioma, reported rates of GTR range from 16.7 to $100 \%$ 6,9,13,15,23,24,38,49 (Table 6). In the present series, the initial goal of the procedure in most cases was complete resection and cure, but when a considerable potential for decrement in the patient's preoperative function was realized, resection was often suspended in favor of an STR followed by postoperative radiosurgery. Five of the 10 patients $(50 \%)$ who experienced an STR or NTR have been treated with fractionated linear accelerator-based radiosurgery. Four of the remaining 5 are undergoing followup using serial MR imaging scans, and 1 foreign-born patient is receiving follow-up care by an oncologist in his country of origin.

The initial visual complications of craniopharyngioma are often progressive visual field defects, which may result in permanent visual loss if the tumor compression is not relieved..$^{30}$ In this series, all patients presented with some degree of objective visual loss (Table 3). Visual improvement after transnasal resection of craniopharyngiomas has been reported in 50 to $93 \%$ of patients. $3,6,9,11,13,15,20,23,24,37,38,49,53$ In the present series, visual acuity and field deficits had either improved $(85.7 \%)$ or resolved $(42.9 \%)$ in most patients at 1 month follow-up. In series including radical resections, the rate of visual deterioration is approximately $15 \% .{ }^{20,46,53}$ In the current series, 1 patient did experience a decrease in visual acuity postoperatively, which was believed to be caused by increased intraoperative manipulation of the optic chiasm, secondary to tumor invasion.

Upon presentation, craniopharyngiomas often demonstrate laboratory evidence of hypogonadism (75-80\%) and growth hormone deficiency (80-100\%). A more moderate degree of adrenal insufficiency (30-60\%) and hypothyroidism $(20-40 \%)$ is frequently noted, while the rate of DI (10-20\%) is less common..$^{27,31}$ Abundant rates of postoperative pituitary deficiency have been reported in multiple surgical series..$^{14,30,44,48}$ Yaşargil et al.$^{56}$ reported permanent DI in $98.7 \%$ of patients. Jung et al. ${ }^{30}$ reported that preservation of the pituitary stalk could result in a protection of pituitary function, with $58.3 \%$ of the patients in their series requiring complete hormone replacement therapy. Other series of endonasal endoscopic craniopharyngioma resections have reported a prevalence of postoperative anterior pituitary dysfunction between 57.1 and $100 \%$, and rates of DI ranging from 56.3 to $100 \%$ based on the aggressivity of the resection ${ }^{6,9,13,15,23,24,38,49}$ (Table 6). In the present series, the authors report a rate of hypopituitarism of any axis of $57.1 \%$ at 1-month follow-up. Temporary or permanent DI was noted in of $64.3 \%$ of patients, while at 1 -month follow-up only 1 patient $(7.1 \%)$ was noted to have DI (considered permanent) after tumor resection. The extent of resection showed a nonsignificant trend toward more patients with GTRs experiencing temporary DI ( $\mathrm{p}=$ 0.12). Throughout the literature, preoperative endocrinological defects rarely recovered after surgery, regardless of the operative approach. ${ }^{11,16,27,28,31}$ In the present series, 1 patient's adrenal insufficiency resolved, but continued to require treatment for hypothyroidism with hormone replacement at 1-month follow-up (Table 4).

In performing a purely endoscopic resection, the main complications are primarily related to control of intracranial vessels (should they be lacerated), and skull base reconstruction with its associated risk of CSF leak, tension pneumocephalus, and meningitis. ${ }^{10}$ In the present series no patient experienced damage to a neurovas- 
TABLE 6: Literature review of outcomes after endoscopic endonasal approach to craniopharyngioma resections*

\begin{tabular}{|c|c|c|c|c|c|c|c|}
\hline \multirow[b]{2}{*}{ Authors \& Year } & \multirow{2}{*}{$\begin{array}{c}\text { No. of } \\
\text { Patients }\end{array}$} & \multirow{2}{*}{$\begin{array}{c}\text { Tumor Size }>2 \\
\mathrm{~cm}(\%)\end{array}$} & \multirow{2}{*}{$\begin{array}{c}\text { Postop Endocrinology } \\
\text { DI (\%)/HP (\%) }\end{array}$} & \multicolumn{2}{|c|}{ Postop Ophthalmology } & \multirow[b]{2}{*}{ GTR $(\%)$} & \multirow{2}{*}{$\begin{array}{c}\text { CSF } \\
\text { Leak (\%) }\end{array}$} \\
\hline & & & & No Deficit (\%) & Improved (\%) & & \\
\hline Cappabianca et al., 2002 & 4 & NR & NR & NR & NR & 100 & NR \\
\hline Frank et al., 2006 & 10 & 80 & $60 / 100$ & 40 & 70 & 70 & 30 \\
\hline Laufer et al., 2007 & 4 & 75 & $100 / 100$ & NR & NR & 100 & 0 \\
\hline de Divitiis et al., 2007 & 10 & NR & $60 / 60$ & 30 & 50 & 70 & 20 \\
\hline Stamm et al., 2008 & 7 & NR & $85.7 \% / N R$ & 57.1 & 67 & 57 & 29 \\
\hline Gardner et al., 2008 & 16 & 81.3 & $56.3 / 88.3$ & 50 & 75 & 50 & 58 \\
\hline Cavallo et al., 2009† & 22 & 91.0 & $72.7 / 91.0$ & 36.4 & 68.1 & 40.9 & 13.6 \\
\hline Dehdashti et al., 2009 & 6 & NR & 50/NR & 16.7 & 80 & 16.7 & 33.3 \\
\hline current study & 14 & 85.7 & $64.3 / 57.1$ & 42.9 & 85.7 & 28.6 & 35.7 \\
\hline
\end{tabular}

* $\mathrm{HP}=$ partial or complete hypopituitarism; NR = not reported.

$\dagger$ Series of recurrent and revision cases only.

cular structure. The reported rates of CSF leakage after endoscopic craniopharyngioma resection range from 0 to $58 \%$. ${ }^{6,9,13,15,23,24,38,49}$ Most series report a decline in the rates of CSF leakage as the authors became more proficient in skull base reconstruction. ${ }^{9,24}$ The introduction of a septal-mucosal flap described by Hadad et al. ${ }^{25,35}$ has shown clinical utility in reducing CSF leaks in the setting of high flow fistulas. In the current series, the authors report an overall CSF leak rate of $35.7 \%$. However, the leak rate has significantly fallen over time as the authors have adopted the nasoseptal flap as well as a fascial "button" for reconstruction of the skull base in the setting of high flow leaks. Nine (64.3\%) of 14 patients underwent a button-augmented closure, with CSF leaks occurring in 2 of these 9 patients. When comparing the duration since the beginning of this series, logistic regression analysis proved the authors achieved a statistically significant $(\mathrm{p}$ $=0.0481$ ) reduction in CSF leak rates by the end of the study period (Fig. 3).
All patients underwent primary endoscopic repair as the procedure of choice to repair postoperative CSF leaks without additional morbidity. Two (14.2\%) of 14 patients required VP shunt placement secondary to hydrocephalus. Two patients $(14.2 \%)$ were treated for meningitis postoperatively. Neither patient received a lumbar drain at any time during their hospitalization, nor did they experience a CSF fistula. Both were treated with an intravenous antibiotic regimen based on the recommendation of infectious disease consultants.

There was 1 death in this series. This patient was a 51-year-old man who presented initially with visual loss, headaches, and hydrocephalus. He underwent an attempted endoscopic resection of a solid adamantinomatous craniopharyngioma with a sizable residual secondary to rigorous adherence to neurovascular structures. One month later, this patient presented with recurrent hydrocephalus and a cystic recurrence, at which time an open craniotomy was performed and an NTR was achieved.

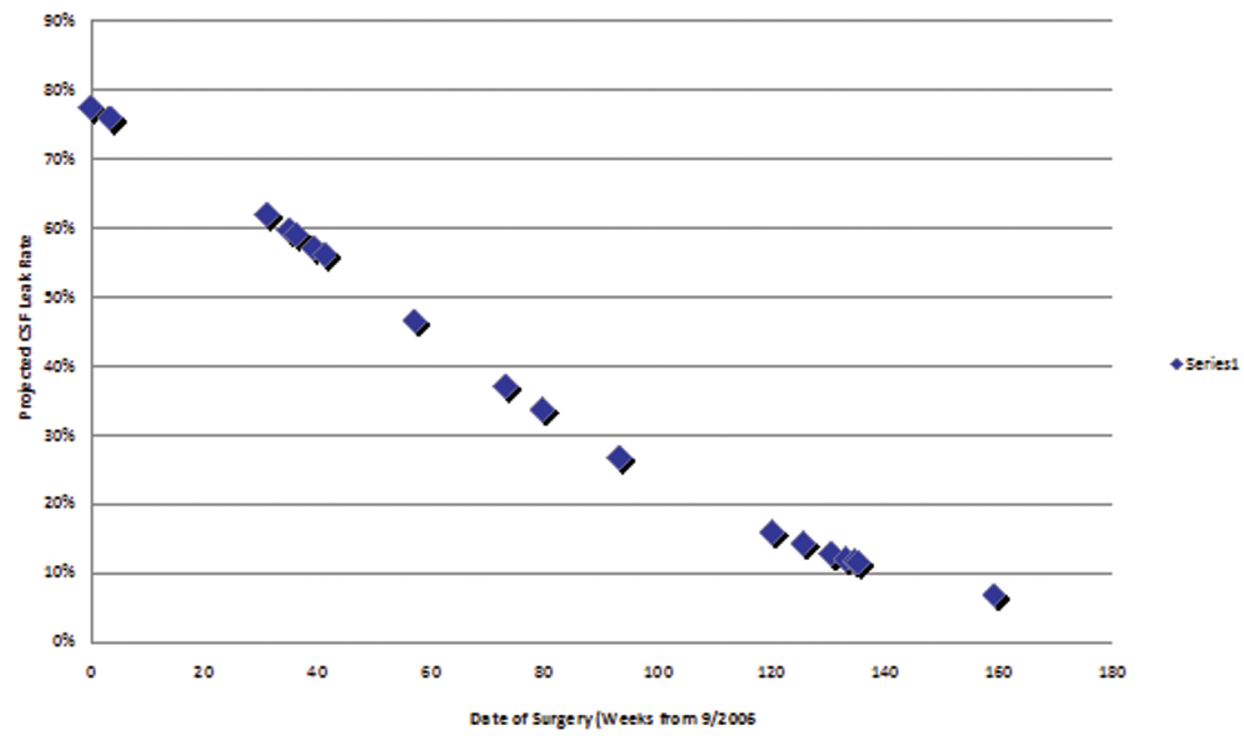

FIG. 3. Graph of the logistic regression analysis of the CSF leak rate over time showing a decrease in the leak rate. 


\section{Outcomes in initial endoscopic resection of craniopharyngioma}

However, the patient's hydrocephalus did not resolve and he subsequently underwent shunt placement. Over the next 5 months, the patient's hydrocephalus was treated with multiple ventriculostomy catheters, VP shunt placements, and revisions. Pathological evaluation of the viscous output from the external ventricular drains revealed a dense cellular and proteinaceous fluid believed to be produced by the tumor. It was postulated that this viscous fluid was responsible for the multiple shunt failures. Ultimately, the patient's family was unwilling to continue surgical intervention and the patient died secondary to hydrocephalus.

\section{Conclusions}

The extent of resection, along with the choice of surgical approach, has a significant effect on the rate of ophthalmological and endocrinological dysfunction after craniopharyngioma resection. Although not all tumors are amenable to an endonasal endoscopic approach, this small case series appears to support its use to provide a high rate of endocrine function preservation and visual recovery, while simultaneously attaining substantial resections. Other small case series in the literature demonstrate reasonable resection rates corresponding to favorable ophthalmological and endocrinological outcomes. A purely endoscopic technique, in appropriately selected patients, can substitute for classic transcranial approaches and allow safe and effective management of craniopharyngiomas with comparable outcomes.

\section{Disclosure}

The authors report no conflict of interest concerning the materials or methods used in this study or the findings specified in this paper.

Author contributions to the study and manuscript preparation include the following. Conception and design: PG Campbell, B McGettigan, A Luginbuhl, JJ Evans. Acquisition of data: PG Campbell, B McGettigan, A Luginbuhl, S Yadla. Analysis and interpretation of data: PG Campbell, B McGettigan, A Luginbuhl, JJ Evans. Drafting the article: PG Campbell, JJ Evans. Critically revising the article: PG Campbell, B McGettigan, S Yadla, M Rosen, JJ Evans. Reviewed final version of the manuscript and approved it for submission: PG Campbell, B McGettigan, A Luginbuhl, S Yadla, M Rosen, JJ Evans. Statistical analysis: PG Campbell. Administrative/ technical/material support: B McGettigan.

\section{References}

1. Adamson TE, Wiestler OD, Kleihues P, Yaşargil MG: Correlation of clinical and pathological features in surgically treated craniopharyngiomas. J Neurosurg 73:12-17, 1990

2. Banna M, Hoare RD, Stanley P, Till K: Craniopharyngioma in children. J Pediatr 83:781-785, 1973

3. Baskin DS, Wilson CB: Surgical management of craniopharyngiomas. A review of 74 cases. J Neurosurg 65:22-27, 1986

4. Batra PS, Citardi MJ, Lanza DC: Isolated sphenoid sinusitis after transsphenoidal hypophysectomy. Am J Rhinol 19:185189,2005

5. Cabezudo JM, Vaquero J, Areitio E, Martinez R, de Sola RG, Bravo G: Craniopharyngiomas: a critical approach to treatment. J Neurosurg 55:371-375, 1981
6. Cappabianca P, Cavallo LM, Colao A, Del Basso De Caro M, Esposito F, Cirillo S, et al: Endoscopic endonasal transsphenoidal approach: outcome analysis of 100 consecutive procedures. Minim Invasive Neurosurg 45:193-200, 2002

7. Carmel PW, Antunes JL, Chang CH: Craniopharyngiomas in children. Neurosurgery 11:382-389, 1982

8. Casler JD, Doolittle AM, Mair EA: Endoscopic surgery of the anterior skull base. Laryngoscope 115:16-24, 2005

9. Cavallo LM, Prevedello DM, Solari D, Gardner PA, Esposito F, Snyderman $\mathrm{CH}$, et al: Extended endoscopic endonasal transsphenoidal approach for residual or recurrent craniopharyngiomas. J Neurosurg 111:578-589, 2009

10. Ceylan S, Koc K, Anik I: Extended endoscopic approaches for midline skull-base lesions. Neurosurg Rev 32:309-319, 2009

11. Chakrabarti I, Amar AP, Couldwell W, Weiss MH: Longterm neurological, visual, and endocrine outcomes following transnasal resection of craniopharyngioma. J Neurosurg 102:650-657, 2005

12. Couldwell WT, Weiss MH, Rabb C, Liu JK, Apfelbaum RI, Fukushima T: Variations on the standard transsphenoidal approach to the sellar region, with emphasis on the extended approaches and parasellar approaches: surgical experience in 105 cases. Neurosurgery 55:539-550, 2004

13. de Divitiis E, Cappabianca P, Cavallo LM, Esposito F, de Divitiis $\mathrm{O}$, Messina A: Extended endoscopic transsphenoidal approach for extrasellar craniopharyngiomas. Neurosurgery 61 (5 Suppl 2):219-228, 2007

14. De Vile CJ, Grant DB, Kendall BE, Neville BG, Stanhope R, Watkins KE, et al: Management of childhood craniopharyngioma: can the morbidity of radical surgery be predicted? J Neurosurg 85:73-81, 1996

15. Dehdashti AR, Ganna A, Witterick I, Gentili F: Expanded endoscopic endonasal approach for anterior cranial base and suprasellar lesions: indications and limitations. Neurosurgery 64:677-689, 2009

16. Di Rocco C, Caldarelli M, Tamburrini G, Massimi L: Surgical management of craniopharyngiomas-experience with a pediatric series. J Pediatr Endocrinol Metab 19 (Suppl 1):355-366, 2006

17. Duff J, Meyer F, Ilstrup D, Laws E, Schleck C, Scheithauer B: Long-term outcomes for surgically resected craniopharyngiomas. Neurosurgery 46:291-305, 2000

18. Dusick JR, Esposito F, Mattozo CA, Chaloner C, McArthur DL, Kelly DF: Endonasal transsphenoidal surgery: the patient's perspective-survey results from 259 patients. Surg Neurol 65:332-342, 2006

19. Esposito F, Cappabianca P, Del Basso De Caro M, Cavallo LM, Rinaldi C, De Divitiis E: Endoscopic endonasal transsphenoidal removal of an intra-suprasellar schwannoma mimicking a pituitary adenoma. Minim Invasive Neurosurg 47:230-234, 2004

20. Fahlbusch R, Honegger J, Paulus W, Huk W, Buchfelder M: Surgical treatment of craniopharyngiomas: experience with 168 patients. J Neurosurg 90:237-250, 1999

21. Fatemi N, Dusick JR, de Paiva Neto MA, Kelly DF: The endonasal microscopic approach for pituitary adenomas and other parasellar tumors: a 10-year experience. Neurosurgery 63 (4 Suppl 2):244-256, 2008

22. Fischer EG, Welch K, Shillito J Jr, Winston KR, Tarbell NJ: Craniopharyngiomas in children. Long-term effects of conservative surgical procedures combined with radiation therapy. J Neurosurg 73:534-540, 1990

23. Frank G, Pasquini E, Doglietto F, Mazzatenta D, Sciarretta V, Farneti G, et al: The endoscopic extended transsphenoidal approach for craniopharyngiomas. Neurosurgery 59 (1 Suppl):ONS75-ONS83, 2006

24. Gardner PA, Kassam AB, Snyderman CH, Carrau RL, Mintz $\mathrm{AH}$, Grahovac S, et al: Outcomes following endoscopic, ex- 
panded endonasal resection of suprasellar craniopharyngiomas: a case series. J Neurosurg 109:6-16, 2008

25. Hadad G, Bassagasteguy L, Carrau RL, Mataza JC, Kassam A, Snyderman CH, et al: A novel reconstructive technique after endoscopic expanded endonasal approaches: vascular pedicle nasoseptal flap. Laryngoscope 116:1882-1886, 2006

26. Hoffman HJ: Surgical management of craniopharyngioma. Pediatr Neurosurg 21 (Suppl 1):44-49, 1994

27. Honegger J, Buchfelder M, Fahlbusch R: Surgical treatment of craniopharyngiomas: endocrinological results. J Neurosurg 90:251-257, 1999

28. Honegger J, Buchfelder M, Fahlbusch R, Däubler B, Dörr HG: Transsphenoidal microsurgery for craniopharyngioma. Surg Neurol 37:189-196, 1992

29. Jho HD, Carrau RL: Endoscopic endonasal transsphenoidal surgery: experience with 50 patients. J Neurosurg 87:44-51, 1997

30. Jung TY, Jung S, Choi JE, Moon KS, Kim IY, Kang SS: Adult craniopharyngiomas: surgical results with a special focus on endocrinological outcomes and recurrence according to pituitary stalk preservation. J Neurosurg 111:572-577, 2009

31. Karavitaki N, Brufani C, Warner JT, Adams CB, Richards P, Ansorge $\mathrm{O}$, et al: Craniopharyngiomas in children and adults: systematic analysis of 121 cases with long-term follow-up. Clin Endocrinol (Oxf) 62:397-409, 2005

32. Karavitaki N, Cudlip S, Adams CB, Wass JA: Craniopharyngiomas. Endocr Rev 27:371-397, 2006

33. Karavitaki N, Wass JA: Craniopharyngiomas. Endocrinol Metab Clin North Am 37:173-193, 2008

34. Kassam AB, Gardner PA, Snyderman CH, Carrau RL, Mintz AH, Prevedello DM: Expanded endonasal approach, a fully endoscopic transnasal approach for the resection of midline suprasellar craniopharyngiomas: a new classification based on the infundibulum. J Neurosurg 108:715-728, 2008

35. Kassam AB, Thomas A, Carrau RL, Snyderman CH, Vescan A, Prevedello D, et al: Endoscopic reconstruction of the cranial base using a pedicled nasoseptal flap. Neurosurgery 63 (Suppl 1):ONS44-ONS 53, 2008

36. Komotar RJ, Roguski M, Bruce JN: Surgical management of craniopharyngiomas. J Neurooncol 92:283-296, 2009

37. König A, Lüdecke DK, Herrmann HD: Transnasal surgery in the treatment of craniopharyngiomas. Acta Neurochir (Wien) 83:1-7, 1986

38. Laufer I, Anand VK, Schwartz TH: Endoscopic, endonasal extended transsphenoidal, transplanum transtuberculum approach for resection of suprasellar lesions. J Neurosurg 106: $400-406,2007$

39. Laws ER Jr: Transsphenoidal microsurgery in the management of craniopharyngioma. J Neurosurg 52:661-666, 1980

40. Maira G, Anile C, Rossi GF, Colosimo C: Surgical treatment of craniopharyngiomas: an evaluation of the transsphenoidal and pterional approaches. Neurosurgery 36:715-724, 1995

41. Merchant TE, Kiehna EN, Sanford RA, Mulhern RK, Thompson SJ, Wilson MW, et al: Craniopharyngioma: the St. Jude Children's Research Hospital experience 1984-2001. Int J Radiat Oncol Biol Phys 53:533-542, 2002

42. Minamida Y, Mikami T, Hashi K, Houkin K: Surgical management of the recurrence and regrowth of craniopharyngiomas. J Neurosurg 103:224-232, 2005
43. Nelson JS (ed): Principles and Practice of Neuropathology, ed 2. Oxford; New York: Oxford University Press, 2003

44. Paja M, Lucas T, García-Uría J, Salamé F, Barceló B, Estrada J: Hypothalamic-pituitary dysfunction in patients with craniopharyngioma. Clin Endocrinol (Oxf) 42:467-473, 1995

45. Scott RM, Hetelekidis S, Barnes PD, Goumnerova L, Tarbell NJ: Surgery, radiation, and combination therapy in the treatment of childhood craniopharyngioma-a 20-year experience. Pediatr Neurosurg 21 (Suppl 1):75-81, 1994

46. Shi XE, Wu B, Zhou ZQ, Fan T, Zhang YL: Microsurgical treatment of craniopharyngiomas: report of 284 patients. Chin Med J (Engl) 119:1653-1663, 2006

47. Shirane R, Ching-Chan S, Kusaka Y, Jokura H, Yoshimoto T: Surgical outcomes in 31 patients with craniopharyngiomas extending outside the suprasellar cistern: an evaluation of the frontobasal interhemispheric approach. J Neurosurg 96:704712,2002

48. Sorva R, Heiskanen O, Perheentupa J: Craniopharyngioma surgery in children: endocrine and visual outcome. Childs Nerv Syst 4:97-99, 1988

49. Stamm AC, Vellutini E, Harvey RJ, Nogeira JF Jr, Herman DR: Endoscopic transnasal craniotomy and the resection of craniopharyngioma. Laryngoscope 118:1142-1148, 2008

50. Sung DI: Suprasellar tumors in children: a review of clinical manifestations and managements. Cancer 50:1420-1425, 1982

51. Symon L, Sprich W: Radical excision of craniopharyngioma. Results in 20 patients. J Neurosurg 62:174-181, 1985

52. Thomsett MJ, Conte FA, Kaplan SL, Grumbach MM: Endocrine and neurologic outcome in childhood craniopharyngioma: review of effect of treatment in 42 patients. J Pediatr 97:728-735, 1980

53. Van Effenterre R, Boch AL: Craniopharyngioma in adults and children: a study of 122 surgical cases. J Neurosurg 97:3-11, 2002

54. Weiner HL, Wisoff JH, Rosenberg ME, Kupersmith MJ, Cohen H, Zagzag D, et al: Craniopharyngiomas: a clinicopathological analysis of factors predictive of recurrence and functional outcome. Neurosurgery 35:1001-1010, 1994

55. Weiss M, Sutton L, Marcial V, Fowble B, Packer R, Zimmerman R, et al: The role of radiation therapy in the management of childhood craniopharyngioma. Int J Radiat Oncol Biol Phys 17:1313-1321, 1989

56. Yaşargil MG, Curcic M, Kis M, Siegenthaler G, Teddy PJ, Roth P: Total removal of craniopharyngiomas. Approaches and long-term results in 144 patients. J Neurosurg 73:3-11, 1990

57. Zülch KJ: Histological Typing of Tumours of the Central Nervous System. Geneva: World Health Organization, 1979

Manuscript submitted November 22, 2009.

Accepted January 5, 2010.

Part of these results were presented as an oral presentation at the North American Skull Base Society meeting on October 18, 2009, in New Orleans, Louisiana.

Address correspondence to: Peter G. Campbell, M.D., Department of Neurosurgery, 909 Walnut St,3rd Floor,Philadelphia,Pennsylvania 19107. email: peter.campbell@jeffersonhospital.org. 